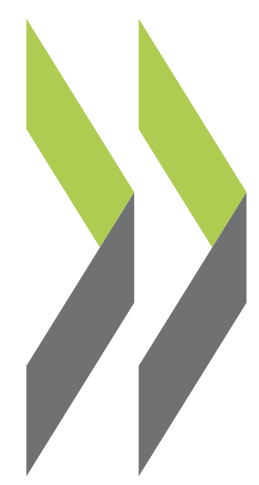

OECD Economics Department Working Papers No. 767

Assessing the Impact of the Financial Crisis Stéphanie Guichard, on Structural Unemployment Elena Rusticelli in OECD Countries 
Organisation de Coopération et de Développement Économiques

Organisation for Economic Co-operation and Development

14-Oct-2010

ECONOMICS DEPARTMENT

English text only

Cancels \& replaces the same document of 05 May 2010

ASSESSING THE IMPACT OF THE FINANCIAL CRISIS ON STRUCTURAL UNEMPLOYMENT IN OECD COUNTRIES

ECONOMICS DEPARTMENT WORKING PAPER No.767

by

Stéphanie Guichard and Elena Rusticelli

All Economics Department Working Papers are available through OECD's internet web site at www.oecd.org/eco/workingpapers 


\section{ABSTRACT/RÉSUMÉ}

\section{Assessing the Impact of the Financial Crisis on Structural Unemployment in OECD Countries}

The global recession is likely to result in higher structural unemployment for some time in many OECD countries. This paper assesses how the shock to aggregate unemployment as a result of the economic crisis may be transmitted to structural unemployment through hysteresis effects that occur through the rise in long-term unemployment. The estimated increase in structural unemployment due to the crisis is estimated at $3 / 4$ percentage point in the OECD as a whole, but the paper highlights wide crosscountry differences with the largest increases expected in those European countries where unemployment is increasing most and where institutional settings remain less favorable than elsewhere, notably Spain and Ireland.

JEL Classification: C13; C22; E24; E31; J38; J58; J68

Key words: Unemployment; NAIRU; Phillips curve; institutions; long-term unemployment, hysteresis

$* * * * * * * * * * * * * * * * * * * * * * * * *$

\section{Évaluation de l'impact de la crise financière sur le chômage structurel dans les pays de l'OCDE}

La récession mondiale est susceptible d'entrainer un chômage structurel plus élevé pendant un certain temps dans de nombreux pays de l'OCDE. Ce document examine comment le choc sur le chômage global résultant de la crise économique peut être transmis au chômage structurel par des effets d'hystérésis qui se produisent via la montée du chômage de longue durée. L'augmentation estimée de chômage structurel résultant de la crise est estimée à $3 / 4$ de point de pourcentage pour l'OCDE dans son ensemble, mais cette étude souligne les différences importantes entre pays, avec notamment les plus grandes augmentations attendues dans les pays européens où l'environnement institutionnel demeure moins favorable qu'ailleurs, notamment l'Espagne et l'Irlande.

Classification JEL : C13 ; C22 ; E24 ; E31 ; J38 ; J58 ; J68

Mots clés : Chômage ; NAIRU ; courbe de Phillips ; institutions ; chômage de longue durée ; hystérésis 


\section{TABLE OF CONTENTS}

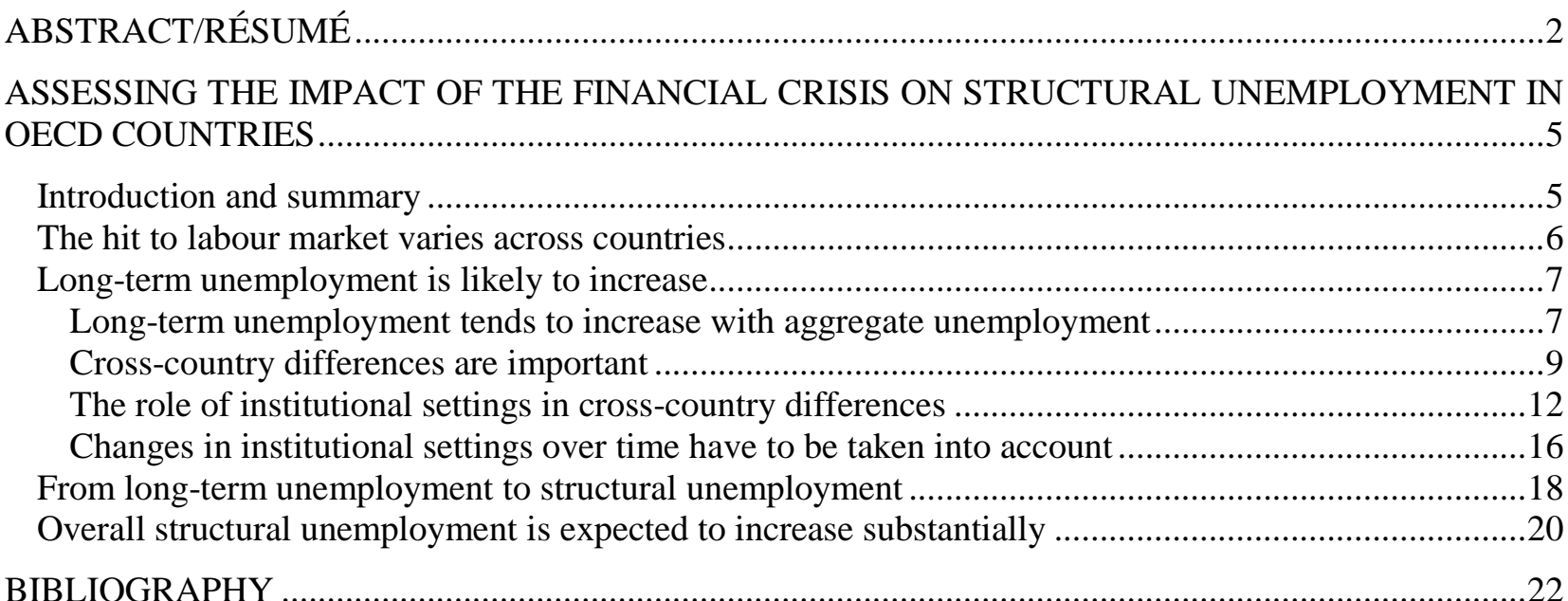

\section{Boxes}

Box 1. Institutional settings affecting long-term unemployment

\section{Tables}

1. Summary of estimations results of long-term unemployment equations .8

2. Estimation results on the determinant of long-term unemployment without ALMP .........................14

3. Estimation results on the determinant of long-term unemployment with ALMP .............................15

4. A measure of the relative influence of long-term unemployment on inflation .................................19

5. Summary of the country's vulnerability to an increase in structural unemployment........................21

\section{Figures}

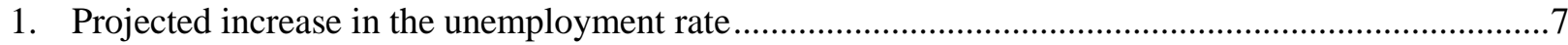

2. Long-term impact of a unit increase of unemployment on its long-term component .........................9

3. The impact of a unit increase of unemployment on long-term unemployment.................................10

4. Selected institutions and the response of long-term unemployment to actual unemployment............12

5. Impact of changing institutions on the response on long-term unemployment to aggregate

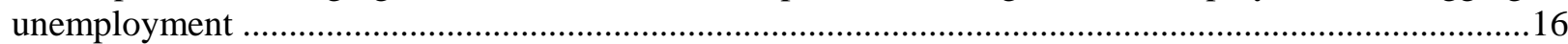

6. Expected impact of the crisis on long-term unemployment 2007-12 _.............................................17

7. Projected peak increase in the long-term and structural unemployment rate due to the crisis............20 
ECO/WPK(2010)23 
ECO/WPK(2010)23

\title{
ASSESSING THE IMPACT OF THE FINANCIAL CRISIS ON STRUCTURAL UNEMPLOYMENT IN OECD COUNTRIES
}

\author{
by
}

Stéphanie Guichard and Elena Rusticelli ${ }^{1}$

\section{Introduction and summary}

1. The global recession resulted in a severe shock to labour markets and is likely to reverse the fall in the structural unemployment rate observed in most OECD countries since at least the late 1990s. ${ }^{2}$ The number of unemployed in the OECD is expected to increase by over $60 \%$, raising the aggregate OECD unemployment rate from a pre-crisis 18 -year low of $5 \frac{1}{2}$ percent to a projected post-war high of over 9 percent this year. Evidence of previous severe recessions in OECD countries suggests that sharp increases in unemployment following severe recessions are long lasting and often not completely reversed in subsequent recoveries (OECD, 2009). Hysteresis effects are indeed likely to push up structural unemployment as workers that remain unemployed for a long period become less attractive to employers as a result of declining human capital, or as they reduce the intensity of their job search (Machin and Manning, 1998) and put less downward pressure on wages and inflation. Assessing the increase in structural unemployment is necessary to gauge possible inflationary pressure that will arise in the recovery. More generally, structural unemployment is one important factor affecting the supply of labour in an economy and therefore potential output. ${ }^{3}$

1. At the time of writing, the authors were members of the Macroeconomic Analysis Division of the Economics Department. They are grateful to Christophe André, Romain Duval, Jorgen Elmeskov, JeanLuc Schneider and Dave Turner for helpful comments and suggestions on earlier versions of the paper, and to Diane Scott for assistance in preparing the document.

2. The structural unemployment rate is defined as the rate of unemployment consistent with stable inflation (the so-called NAIRU, or non-accelerating inflation rate of unemployment). The general background and details of previous OECD work estimating time-varying NAIRUs within the Phillips curve framework are given by Richardson et al. (2000). The time-varying NAIRU is obtained via the estimation of a reducedform Phillips curve equation using a Kalman filter procedure. The most recent updating exercise (Gianella et al., 2008) suggests that the structural unemployment rate for most OECD economies over the decade to 2007 has fallen substantially, in particular for the euro area. During this period, the decline in the NAIRU raised the rate of potential output by approximately 0.1 percentage point per annum in the euro area and by about half that in the United States.

3. The production function used to analyse project potential output for the Economic Outlook is a constantreturns-to-scale Cobb Douglas production function for the total economy with Harrod-neutral labouraugmenting technical progress as detailed in Beffy et al., 2006. The crisis also affects potential output by other channels such as the cost of capital and labour force participation as described notably in the Special Chapters of the OECD Economic Outlook Nos.85 and 87. 
2. The notion of hysteresis has been borrowed from physics to account for the lasting effects of transitory shocks so that structural unemployment may be influenced by the path of actual unemployment. Long-term unemployment plays a key role in hysteresis effects, as suggested notably by Ball (2009). Workers who have been unemployed for some time tend to become less attractive to employers. Not only human capital of the unemployed diminishes over time, but also as a result of recruitment costs, potential employees are frequently evaluated on the basis of frequency and duration of their periods of unemployment (Lockwood, 1991). Job search may also diminish as the unemployed lose contact with the labour market and awareness of job offers. In addition, long-term unemployed may put less pressure on wages because long unemployment spells can increase their reservation wage as a consequence of a social acceptance of their status (Lindbeck, 1995), and the human capital of the unemployed may fall below the reservation wage (Blanchard and Summers, 1991). Indeed, there is empirical evidence that long-term unemployed have less influence on wage bargaining than the short-term unemployed (Llaudes, 2005 and Elmeskov and MacFarlan, 1993), and thereby prevent real wages from falling sufficiently to get priced back into the labour market and so increases in the proportion of the long-term unemployed may increase the structural unemployment rate consistent with a stable inflation rate. As a result, the focus of the empirical analysis presented below is on the historical links between aggregate, and long-term and structural unemployment, as well as the impact of institutional settings on such links. ${ }^{4}$

3. The main findings are that:

- Thanks to labour and product market reforms, in the majority of countries, the impact of the crisis on long-term and structural unemployment is likely to be more moderate than in past severe downturns.

- Cross-country differences in the behaviour of long-term and structural unemployment as a result of the crisis will not only depend on the magnitude of the initial shock to the labour markets but also on country-specific factors including institutional settings.

- The estimation work, based on past historical evidence, underestimates the magnitude of the long-term unemployment increase observed recently in the United States, suggesting that further investigation of the impact of the crisis on the US labour market is necessary.

4. The next section reviews briefly the impact of the crisis on aggregate unemployment. The empirical sections assess how long-term unemployment has behaved in the past in response to changes in aggregate unemployment (section 3). Section 4 discusses the role of institutions in accounting for crosscountry differences in the sensitivity of long-term unemployment to aggregate unemployment and also changes over time in this sensitivity. The last section examines how higher long-term unemployment affects structural unemployment (section 5).

\section{The hit to labour market varies across countries}

5. The magnitude of the initial shock to labour markets varies widely across countries (Figure 1) and will be the first source of cross-country differences in the impact of the crisis on structural unemployment. There has been considerable variation in labour market developments across OECD countries during the recession (see Figure 1 and Economic Outlook No.86 for more details). While labour

4. In normal times, NAIRU are projected to remain stable unless there are reforms to institutional settings likely to have an impact. The NAIRU projections are then used as a benchmark for projections of unemployment. The logic here is somewhat reversed because it is very likely that the crisis and the resulting huge increase in unemployment will push the NAIRU via hysteresis effect. This change in approach, required to assess the implication of the crisis for potential output, is only temporary. 
market conditions deteriorated almost everywhere, the extent of the contraction and the form it has taken differ considerably. In many economies, notably in continental Europe, reductions in overtime and shorttime working arrangements have helped limit the rise in unemployment (Germany being the most notable case, see OECD, 2010). By contrast, in the United States, the recession has triggered unusually large job losses, despite some reduction in average hours worked. The increase in unemployment has also been large in those countries most affected by a collapse in the construction sector, especially where it had grown to account for an unusually high share of GDP (Spain and Ireland). ${ }^{5}$

Figure 1. Projected increase in the unemployment rate

Percentage point increase, 2007Q4 to peak

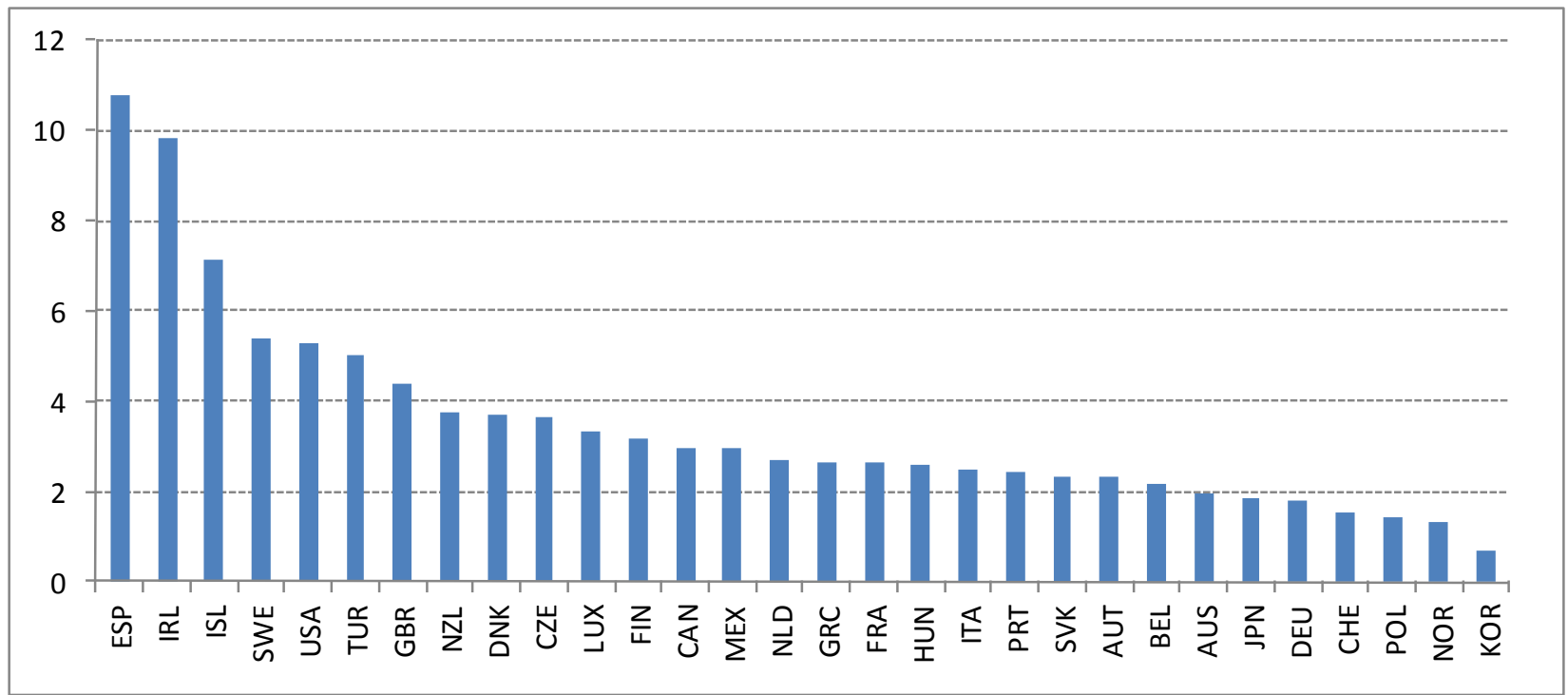

Note: The peak is reached between 2009Q4 and 2011Q2 depending on the country.

Source: OECD Economic Outlook Database 86.

\section{Long-term unemployment is likely to increase}

\section{Long-term unemployment tends to increase with aggregate unemployment}

6. In past episodes of rising unemployment, long-term unemployment (defined here as the number of workers who have been unemployed for more than 12 months) increased substantially. To assess more precisely the sensitivity of long-term unemployment to aggregate unemployment simple dynamic regressions were estimated explaining long-term unemployment in terms of aggregate unemployment. The underlying country specific equations are of the form:

$$
L T U_{i t}=\alpha_{i}+\sum_{i=1}^{4} \beta_{i \mathbb{R}} L T U_{i t-\mathbb{I}}+\sum_{i=0}^{4} \gamma_{i \mathbb{R}} U N R_{i t-\mathbb{l}}+\varepsilon_{i \mathrm{it}}
$$

5. Job losses in the construction sector account for half the total job losses since the beginning of the downturn in Spain and Ireland and about one-quarter in the United States. 
where LTU is the long-term unemployment rate and UNR the unemployment rate (both expressed as a percentage of the aggregate labour force). ${ }^{6}$ These equations have been estimated on a country-by-country basis and the main results of the estimations are provided in Table 1.

Table 1. Summary of estimations results of long-term unemployment equations

\begin{tabular}{|c|c|c|c|c|c|c|c|}
\hline & LTU-1 & LTU-2 & UNR & UNR-1 & UNR-2 & R2 adj & $\begin{array}{c}\text { Effect of a } \\
\text { unit shock } \\
\text { to UNR on } \\
\text { LTU }\end{array}$ \\
\hline Australia & 0.61 & -0.21 & 0.31 & ns & ns & 0.98 & 0.51 \\
\hline Austria & 0.27 & $\mathrm{~ns}$ & 0.32 & ns & ns & 0.38 & 0.44 \\
\hline Belgium & 0.52 & ns & ns & 0.41 & ns & 0.84 & 0.84 \\
\hline Canada & 0.95 & ns & 0.14 & ns & -0.11 & 0.95 & 0.50 \\
\hline Czech Republic & 0.49 & ns & 0.40 & ns & ns & 0.98 & 0.78 \\
\hline Denmark & 0.20 & ns & 0.20 & 0.11 & ns & 0.93 & 0.39 \\
\hline Finland & 0.66 & -0.26 & 0.24 & ns & ns & 0.98 & 0.41 \\
\hline France & 0.34 & ns & 0.32 & ns & ns & 0.95 & 0.49 \\
\hline Germany & 0.40 & ns & 0.51 & ns & ns & 0.99 & 0.85 \\
\hline Greece & 0.58 & ns & 0.62 & -0.33 & ns & 0.97 & 0.67 \\
\hline Hungary & 0.48 & ns & 0.31 & ns & ns & 0.94 & 0.58 \\
\hline Iceland & 0.57 & ns & 0.12 & ns & ns & 0.89 & 0.27 \\
\hline Ireland & 0.37 & ns & 0.47 & ns & ns & 0.99 & 0.75 \\
\hline Italy & 0.70 & ns & 0.73 & -0.47 & ns & 0.93 & 0.86 \\
\hline Japan & 0.61 & ns & 0.18 & ns & ns & 0.99 & 0.47 \\
\hline Korea & ns & ns & ns & 0.01 & ns & 0.86 & 0.01 \\
\hline Luxembourg & ns & ns & 0.14 & ns & 0.12 & 0.79 & 0.26 \\
\hline Mexico & ns & ns & ns & 0.03 & ns & 0.49 & 0.06 \\
\hline Netherlands & 0.29 & ns & 0.44 & ns & ns & 0.97 & 0.62 \\
\hline New Zealand & 0.75 & -0.27 & 0.23 & ns & ns & 0.98 & 0.44 \\
\hline Norw ay & 0.93 & -0.33 & 0.15 & ns & ns & 0.90 & 0.38 \\
\hline Poland & 0.40 & ns & 0.44 & ns & ns & 0.98 & 0.74 \\
\hline Portugal & 0.27 & ns & 0.51 & ns & ns & 0.93 & 0.71 \\
\hline Slovak Republic & 0.61 & ns & 0.23 & 0.49 & -0.39 & 0.98 & 0.85 \\
\hline Spain & 0.32 & ns & 0.55 & ns & ns & 0.98 & 0.80 \\
\hline Sw eden & 0.85 & ns & 0.17 & ns & -0.12 & 0.96 & 0.39 \\
\hline Sw itzerland & 0.35 & ns & 0.15 & 0.20 & ns & 0.87 & 0.55 \\
\hline Turkey & 0.57 & ns & 0.22 & ns & ns & 0.50 & 0.50 \\
\hline United Kingdom & 0.76 & -0.29 & 0.34 & ns & ns & 0.99 & 0.64 \\
\hline United States & 0.77 & -0.22 & 0.08 & ns & ns & 0.77 & 0.17 \\
\hline
\end{tabular}

Note: All reported coefficients are statistically significant to at least a $10 \%$ level (ns indicates non significant coefficients). Constants are not reported here. LTU is the long-term unemployment rate (i.e. unemployment rate for those unemployed for more than 12 months) and UNR the aggregate unemployment rate.

Source: OECD calculations.

6. The long-term unemployment data comes from the OECD labour force statistics and is only available at an annual frequency in most countries. A limitation to the exercise is that the condition for unemployed to be counted as long-term unemployed has changed over time in some countries and still varies across countries. In the very long term, aggregate and long-term unemployment rates are bound to be stationary, even though stationarity is rejected in most cases for the samples we have. In practice, there is some evidence that both series are co-integrated in most countries and have been used in level. 
7. In the majority of OECD countries, long-term unemployment increases with aggregate employment. Most of the long-term impact of a sustained unit increase in unemployment on long-term unemployment takes place in three to four years; in nearly all cases this long-term effect is higher than the actual share of long-term unemployment (Figure 2). As a result, the incidence of long-term unemployment is expected to rise with unemployment.

Figure 2. Long-term impact of a unit increase of unemployment on its long-term component

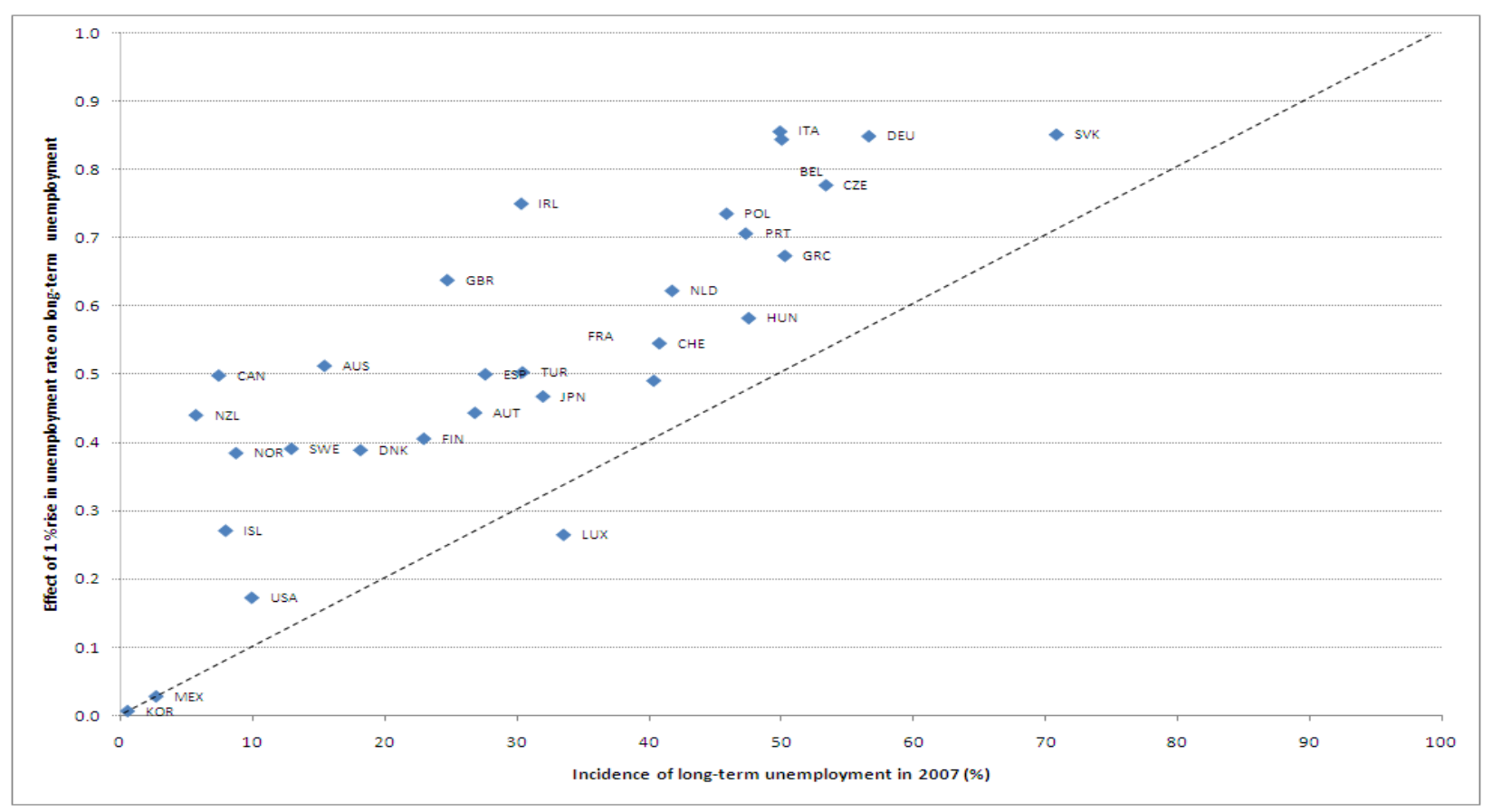

Source: OECD calculations.

\section{Cross-country differences are important}

8. Cross-country differences are important, ranging from a negligible impact in Mexico or Korea to an increase of 0.8 percentage points in the long-term unemployment rate after a 1 percentage point in the aggregate unemployment rate in some euro area countries. ${ }^{7}$ An example of cross-country differences is illustrated by Figure 3 derived from Table 1 which shows the impact of a sustained increase in unemployment on its long-term component for the euro area, Japan and the United States. After a permanent shock on unemployment, on average $70 \%$ of the unemployed eventually became long-term unemployed in Europe, a bit less than half in Japan and less than $20 \%$ in the United States. ${ }^{8}$ Within the euro area differences are also substantial ranging from one-quarter in Luxembourg to over $80 \%$ in Italy.

7. The assumption of a common behaviour, even across some groups of countries, was systematically rejected by the data.

8. As discussed below, the increase in US long-term unemployment since the beginning of the crisis has been much stronger than suggested by past experiences. 
Figure 3. The impact of a unit increase of unemployment on long-term unemployment

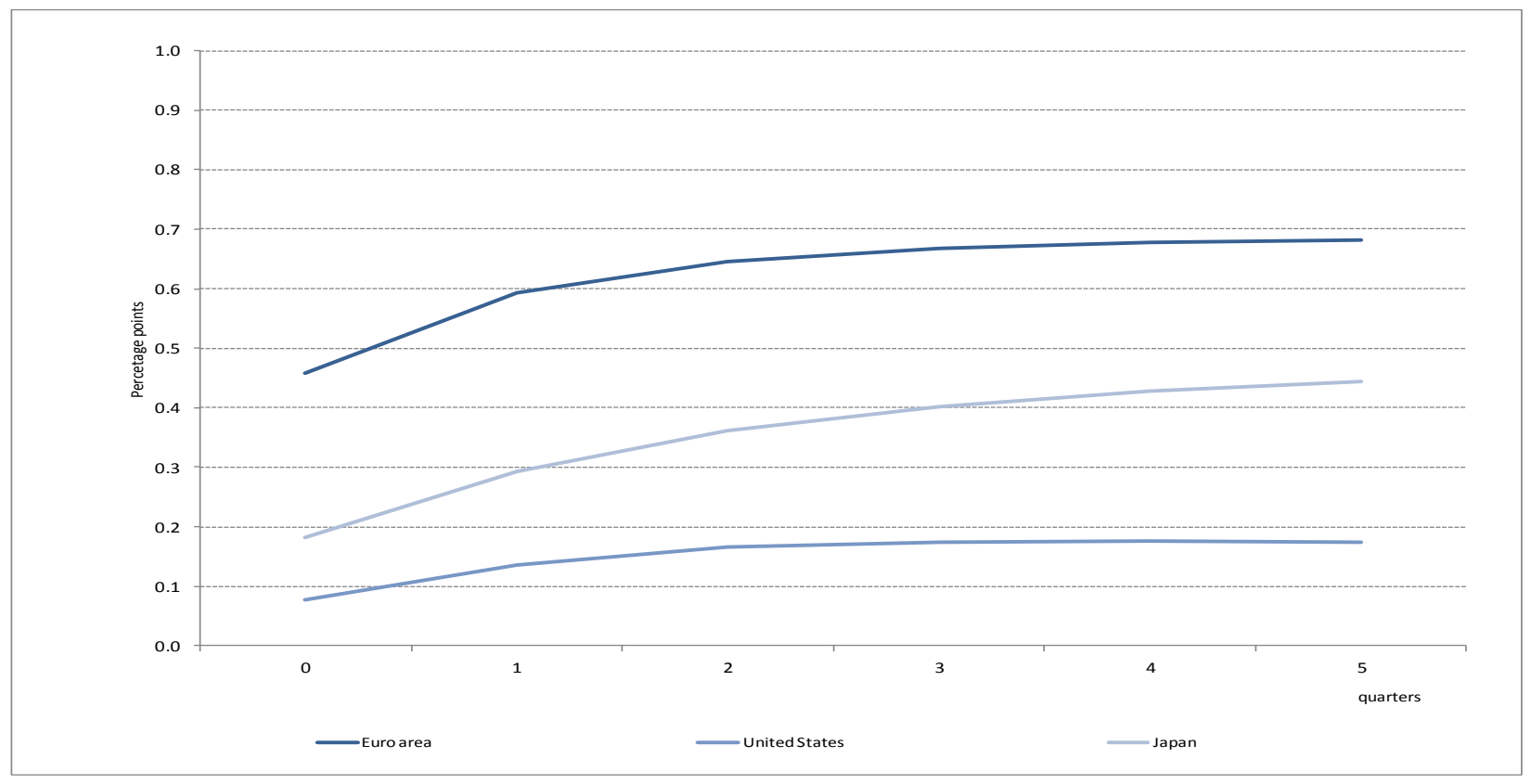

Source: OECD calculation based on estimations summarised in Table 1.

9. Labour and product market institutions and policies are likely to be one key factor behind the different response of long-term unemployment to changes in aggregate unemployment across countries. A number of product and labour market policies and institutions have been identified as possibly influencing long-term unemployment and appear well correlated with long-term unemployment and its incidence (Box 1). Results obtained on the long-term impact of an increase on aggregate unemployment on long-term unemployment also seem quite correlated with at least some of these institutional settings including product market regulation and the role of active labour market policy (Figure 4).

\section{Box 1. Institutional settings affecting long-term unemployment}

A number of product and labour market policies and institutions have been identified as possibly influencing longterm unemployment. Nickell and Layard (1997) and Bassanini and Duval (2006) present a detailed review of the literature on the impact of institutional settings on labour markets, and empirical results on their broad impact on unemployment.

- $\quad$ The level of product market regulation (PMR) may affect the response of long-term unemployment via its impact on the ability of the economy to create job in new activities following a shock. Furthermore, competition friendly PMR may affect the wage-bargaining process by hardening the bargaining position of employers and increase the employment costs of pushing for higher wages.

- While allowing unemployed more time to find better job matches, higher unemployment benefits (ARR) may increase long-term unemployment by reducing job-search intensity and the willingness to accept job offers. This is even more the case of long-term unemployment benefits (LT-ARR) that measure more directly the generosity of unemployment benefits to the long-term unemployed. 
- $\quad$ Tighter employment protection legislation (EPL) tends to lower labour turnover and, by giving more power to insiders and increasing the cost of hiring mistakes, can contribute to increase the length of unemployment spells and the incidence of long-term unemployment. This is even more the case for tighter employment protection legislation for regular workers (EPR), especially relative to non-regular workers.

- $\quad$ More spending on active labour market policies (ALMP) (i.e. on job placement services and labour market programmes) tends to reduce the share of the unemployed that become long-term unemployed, but their impact is difficult to assess. The effectiveness of ALMPs has usually been found to differ significantly between different types of programmes. ALMPs may also just break unemployment spells with training periods, possibly implying a decline in measured long-term unemployment even in the absence of an increase in employability of jobseekers. Another issue is the endogeneity of ALMP to the economic cycle. Expenditures on ALMP may be increased as a response to higher aggregate and long-term-unemployment. Also if expenditures on ALMP do increase proportionally to unemployment, then public expenditures on active labour-market programmes per unemployed will mechanically decline when unemployment increases. However, as explained below, the endogeneity of ALMP was statistically rejected in the model used here.

- A higher tax wedge by increasing labour costs may tend to reduce employment and increases unemployment, although the specific impact on the length of unemployment spells is less clear. Other factors not considered here include the impact of wage floor which may prevent long-term unemployed to price themselves into work; housing policy which may limit workers mobility; as well as the structure of wage bargaining.

Correlations with long-term unemployment and its incidence (calculated over a sample of 30 OECD countries over 21 to 37 years depending on data availability) have the expected signs and are positive and significant for product market regulations, employment protection, and the tax wedge, and negative for active labour market policies. The average replacement rate, including the first year of unemployment benefits, is not significantly correlated with the long-term unemployment rate, whereas the same indicator calculated exclusively over long-term unemployment years shows a significant positive correlation.

\begin{tabular}{|c|c|c|c|c|c|c|c|}
\hline \multirow[t]{2}{*}{ Correlation between } & PMR & EPL & EPR & ARR & LT-ARR & Tax wedge & ALMP \\
\hline & $\begin{array}{l}1975- \\
2008\end{array}$ & $\begin{array}{l}1985- \\
2007\end{array}$ & $\begin{array}{l}1985- \\
2008\end{array}$ & $\begin{array}{l}1970- \\
2007\end{array}$ & $\begin{array}{l}1970- \\
2007\end{array}$ & $1975-2005$ & $1985-2006$ \\
\hline $\begin{array}{l}\text { Long-term unemployment } \\
\text { rate }\end{array}$ & $0.29^{* *}$ & $0.19^{\star \star \star}$ & $0.16^{\star \star \star}$ & 0.02 & 0.06 & $0.23^{* * *}$ & $-0.29^{* * *}$ \\
\hline $\begin{array}{l}\text { Incidence of long-term } \\
\text { unemployment }\end{array}$ & $0.30^{\star \star *}$ & $0.30^{\star * *}$ & $0.24^{\star \star *}$ & $0.12^{\star \star \star}$ & $0.16^{\star * *}$ & $0.26^{\star \star *}$ & $-0.14^{\star \star \star}$ \\
\hline
\end{tabular}

Note: Statistical significance at $1 \%$ and $5 \%$ level is denoted by “***"and "**"respectively. Product Market Regulation (PMR) is OECD indicator summarising regulatory conditions in seven non-manufacturing sectors -- airlines, telecoms, electricity, gas, post, rail and road freight. The average long-term unemployment benefit replacement rate (LT-ARR) is calculated as average unemployment benefit gross replacement rate from the second to the fifth years of unemployment across two income situations (100\% and $67 \%$ of APW earnings), three family situations (single, with dependent spouse, with spouse in work). The tax wedge combines labour and consumption tax rates derived from National Accounts. Employment Protection Legislation on regular contracts (EPR) is the OECD sub-indicator of EPL calculated for dismissals of employees on regular contracts. Active Labour Market Policies (ALMP) measure public expenditures on active labour market programmes per unemployed worker as a share of GDP per capita in percentage for five main categories (public employment services and administration, labour market training, employment incentives, supported employment and rehabilitation and direct job creation).

Source: OECD calculation. 
Figure 4. Selected institutions and the response of long-term unemployment to actual unemployment

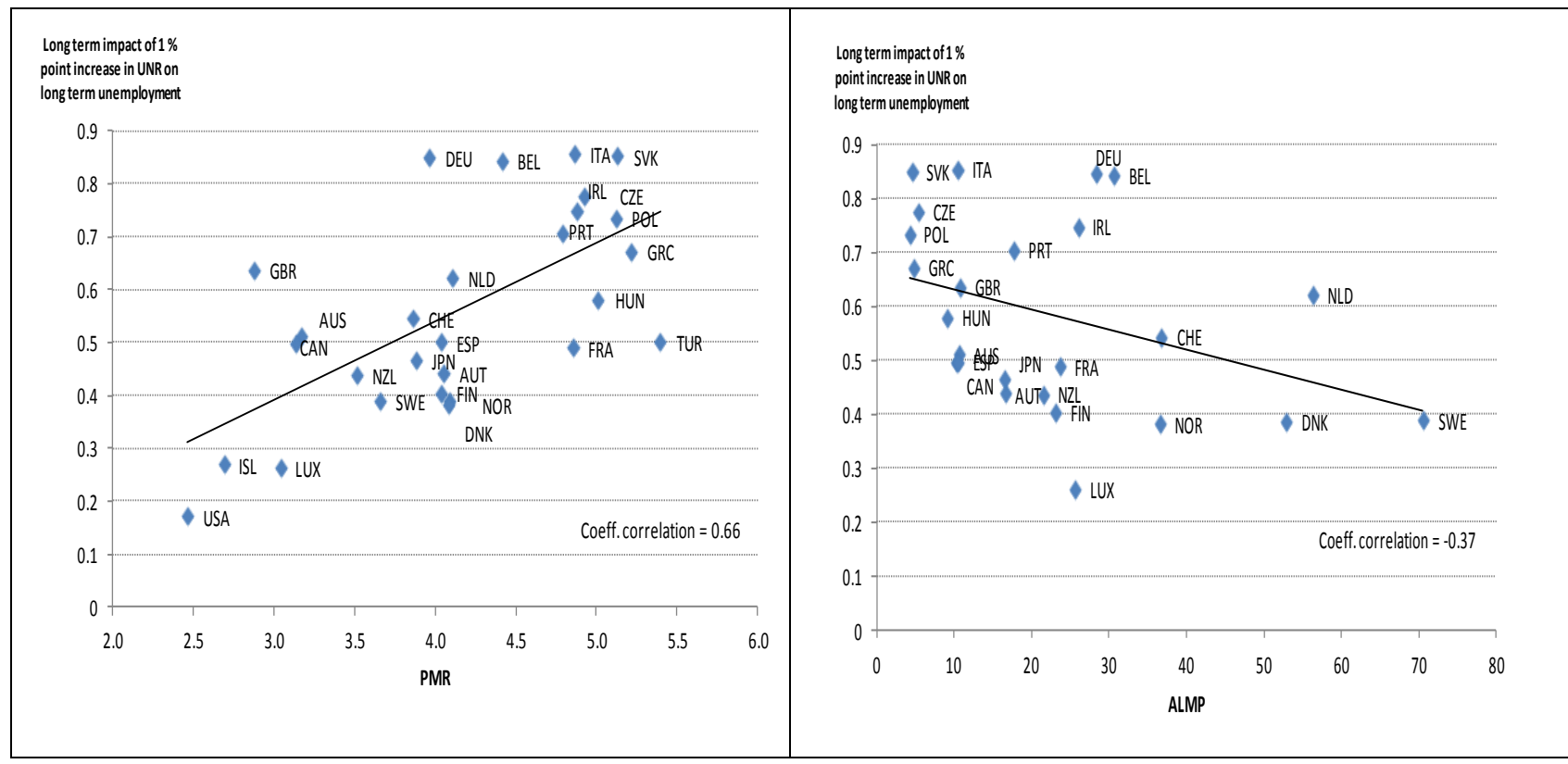

Note: PMR is the Product Market Regulation OECD indicator summarising regulatory conditions in seven non-manufacturing sectors -- airlines, telecoms, electricity, gas, post, rail and road freight. ALMP is a measure of Active Labour Market Policies (public expenditures on active labour market programmes per unemployed worker as a share of GDP per capita in percentage).

Source: OECD calculations.

\section{The role of institutional settings in cross-country differences}

10. Further empirical work has therefore been conducted to investigate the role of institutional settings in the response of long-term unemployment to a shock to aggregate unemployment. A panel regression model, including data for all OECD countries, has been constructed to consider how the response of long-term unemployment ( $L T U)$ to a shock to aggregate unemployment $(U N R)$ depends on institutional settings. For that purpose, institutions and policies have been interacted with a three-year moving average unemployment rate and are expressed as deviations from their respective sample means in the form: ${ }^{9}$

$L T U_{i t}=\alpha_{i}+\beta_{t}+\delta \overline{U N R_{u t}}+\sum_{j} \gamma_{j} I N S T_{i t}^{j}+\sum_{j} \theta_{j}\left(I N S T_{i t}^{j}-\overline{I N S T^{j}}\right)\left(\overline{U N R_{a t}}-\overline{U N R}\right)+\varepsilon_{i t}$

9. A moving averaged aggregate unemployment has been preferred to introducing several lags of aggregate unemployment to facilitate the interaction with institutions. A three-year moving average was retained because the results presented above show that most of the impact of a change in aggregate unemployment is felt on long-term unemployment after three years. The goodness-of-fit deteriorated when using other moving average windows. Using a more complicated dynamic structure did not seem to change the results by much but reduced the number of degrees of freedom. 
where $\alpha_{i}$ and $\beta_{t}$ indicate cross-country and period-fixed effects respectively, and $\delta$ is the coefficient of a three-year moving average of the unemployment rate. The direct stand-alone effect of institutions on longterm unemployment is measured by $\gamma_{j}$, where these coefficients are only representative of the "average country" when both institutions and unemployment are equal to the cross-country average. The marginal effect of institutions interacted with unemployment is given by the coefficients $\theta_{j}{ }^{10}$

11. All institutions and policies described in Box 1 and their respective interactions with unemployment have been considered in unbalanced panel regressions for 26 OECD countries for which the data were available (in most cases staring in the mid-1980s). The panels have been estimated using a seemingly unrelated regression method, which accounts for heteroskedasticity and contemporaneous correlation in the errors across cross-section equations. The presence of significant cross-country and period-fixed effects has been confirmed by the Hausman test and introduced in the model estimation. Institutional variables have not been lagged given their sticky nature. ${ }^{11}$

12. A first set of estimations was run without considering active labour market policies because of the possible endogeneity of this variable and the problems it may create in the estimation. Table 2 reports the results from eight different models, with model 8 being the preferred one. The first four models considered only the interaction of one institution with unemployment while the last four consider a larger set.

13. On average, the long-term unemployment rate increases by about 0.5-0.6 percentage points after three years when the aggregate unemployment rate increases by 1 percentage point which is in line with previous results, but the range varies from $1 / 4$ to $3 / 4$ depending on each country's institutional settings over the estimation period. After controlling for the influence of institutional settings on the level of long-term unemployment, the estimation results suggests that product market regulation, and long-term unemployment benefits play a key role in the transmission of shocks on aggregate unemployment to longterm unemployment. ${ }^{12}$

10. The regression coefficient for the interaction $\theta_{j}$ is a partial regression coefficient. It represents the effect of the interaction if and only if the two explanatory variables involved in the interaction are included also alone in the regression equation (Cohen, 1978). It can be interpreted as the long-term unemployment marginal effect of INST $^{j}$ at its sample mean when aggregate unemployment is kept at its sample mean. From a statistical point of view, centring the variables reduces multi-collinearity caused by the introduction of interaction terms (see Freidrich, 1982; Cronbach, 1987; and Iverson, 1991).

11. A drawback of the analysis is that it does not distinguish asymmetries between the impact of institutions on the response of long-term unemployment when unemployment is decreasing as opposed to increasing. For instance, intuitively, in countries where active labour market policies are important, the increase in longterm unemployment should be less after an increase in aggregate unemployment, but it is less obvious why the decline in long-term unemployment should be less when unemployment is declining.

12. The performance of the system in explaining long-term unemployment, while acceptable in most cases, is particularly weak for a few countries: notably the United States, Korea, and Canada. In the United States and Korea, the system predicts a much higher response of long-term unemployment to aggregate unemployment than individual equations which do not take into account the role of institutions (OECD, 2009b). 
Table 2. Estimation results on the determinant of long-term unemployment without ALMP

\begin{tabular}{|c|c|c|c|c|c|c|c|c|}
\hline Dependant variable LTU & (1) & (2) & (3) & (4) & (5) & (6) & (7) & (8) \\
\hline \multicolumn{9}{|c|}{ Direct effect of policies/institutions } \\
\hline \multirow[t]{2}{*}{ Average unemployment } & $0.56^{\star \star \star}$ & $0.55^{\star * *}$ & $0.58^{* \star *}$ & $0.56^{* \star *}$ & $0.58^{* * *}$ & $0.56^{\star \star \star}$ & $0.56^{* * *}$ & $0.56^{\star * *}$ \\
\hline & {$[0.01]$} & [0.01] & {$[0.01]$} & {$[0.01]$} & {$[0.01]$} & {$[0.01]$} & {$[0.01]$} & [0.01] \\
\hline \multirow[t]{2}{*}{ Product market regulation } & $0.09^{\star \star \star}$ & $0.21^{* * *}$ & $0.25^{\star \star \star}$ & $0.22^{* * *}$ & $0.09^{* * *}$ & $0.08^{* * *}$ & $0.08^{* * *}$ & $0.09^{* * *}$ \\
\hline & {$[0.01]$} & {$[0.01]$} & {$[0.01]$} & [0.01] & {$[0.01]$} & {$[0.01]$} & {$[0.01]$} & {$[0.01]$} \\
\hline \multirow[t]{2}{*}{$\begin{array}{l}\text { Employment protection for } \\
\text { regular employees }\end{array}$} & 0.02 & $0.12^{\star *}$ & $0.42^{\star * \star}$ & -0.03 & $0.08^{*}$ & $0.14^{\star \star \star}$ & $0.16^{\star \star *}$ & 0.03 \\
\hline & {$[0.06]$} & {$[0.06]$} & {$[0.05]$} & {$[0.06]$} & {$[0.05]$} & {$[0.07]$} & {$[0.06]$} & {$[0.07]$} \\
\hline \multirow[t]{2}{*}{$\begin{array}{l}\text { Long-term unemployment } \\
\text { benefits }\end{array}$} & $-0.72^{\star \star \star}$ & $-1.76^{\star \star \star}$ & & $-1.80^{\star * \star}$ & & $-0.77^{\star \star \star *}$ & $-0.92^{\star * *}$ & $-0.87^{\star * *}$ \\
\hline & {$[0.15]$} & {$[0.16]$} & & {$[0.17]$} & & {$[0.15]$} & {$[0.18]$} & {$[0.17]$} \\
\hline \multicolumn{9}{|c|}{ Interactions effect of policies/institutions } \\
\hline \multirow[t]{2}{*}{$\begin{array}{l}\text { Product market regulation } \\
{ }^{*} \text { Average unemployment }\end{array}$} & $0.08^{\star * *}$ & & & & $0.09^{* * *}$ & $0.08^{* \star *}$ & $0.08^{\star * *}$ & $0.08^{\star * *}$ \\
\hline & {$[0.01]$} & & & & {$[0.01]$} & {$[0.01]$} & {$[0.01]$} & {$[0.01]$} \\
\hline \multirow[t]{2}{*}{$\begin{array}{l}\text { Employment protection for } \\
\text { regular employees* Average } \\
\text { unemployment }\end{array}$} & & $-0.05^{\star \star \star}$ & $0.01^{\star *}$ & & -0.002 & $-0.03^{\star * *}$ & $-0.03^{* * *}$ & \\
\hline & & {$[0.01]$} & {$[0.00]$} & & {$[0.00]$} & {$[0.01]$} & {$[0.01]$} & \\
\hline \multirow[t]{2}{*}{$\begin{array}{l}\text { Long-term unemployment } \\
\text { benefits }{ }^{*} \text { Average } \\
\text { unemployment }\end{array}$} & & & & 0.03 & & & $0.10^{\star * \star}$ & $0.09^{* \star *}$ \\
\hline & & & & {$[0.02]$} & & & {$[0.03]$} & {$[0.03]$} \\
\hline Observations included & 414 & 414 & 446 & 414 & 446 & 414 & 414 & 414 \\
\hline
\end{tabular}

Note: Standard errors of the estimates in brackets, ${ }^{*}$ significant at $10 \% ;{ }^{* *}$ significant at $5 \%$; ${ }^{* * *}$ significant at $1 \%$,

Source: OECD calculations.

14. Where product market regulations are more stringent not only is the level of long-term unemployment higher (by about 0.1 to 0.25 percentage points per unit of PMR), but also the response of long-term unemployment to a shock on aggregate unemployment. Thus, the countries which have currently the most competition-friendly product market regulation (such as in the United Kingdom or Germany) would have a response of long-term unemployment 0.2 percentage points lower for each percentage point shock to the aggregate unemployment rate than countries with the least competition-friendly product market regulation (such as Greece or Turkey). Similarly, the difference between countries with the most generous long-term unemployment benefits replacement rates (Denmark in the mid-1990s) and the least generous (no benefits after a year of unemployment as is the case in several countries) will tend to increase the response of long-term unemployment by 0.1 percentage points for each percentage point shock to the aggregate unemployment rate. ${ }^{13}$ On the other hand, the tax wedge and employment protection were not found to have a significant and/or correctly signed impact on long-term unemployment. The level of protection for regular employees seems to have a positive and significant direct effect on long-term unemployment (ceteris paribus a lower EPR by one standard deviation would lead to an average lower

13. This is consistent with results in the existing literature that suggest a positive relationship between the replacement rate and the unemployment rate (Bassanini and Duval, 2006; Blanchard and Wolfers, 2000) and recent results that indicate that higher benefit replacement rates tends to reduce unemployment outflow rates (OECD, 2009), which together would imply longer unemployment spells. 
long-term unemployment of 0.04 percentage points), but its impact on the transmission of unemployment shocks is unclear and depends on the countries included in the sample. ${ }^{14}$

15. Active labour market policies are shown to reduce both the level of long-term unemployment and the response of long-term unemployment to actual unemployment (Table 3). The results on the other institutions are not much affected by the introduction or not of active labour market policies. The endogeneity of ALMP has been tested but rejected in all nine models. Still, the estimated impact of ALMP could also only reflect that active labour market policies just break unemployment spells.

Table 3. Estimation results on the determinant of long-term unemployment with ALMP

\begin{tabular}{|c|c|c|c|c|c|c|c|c|c|}
\hline Dependant variable LTU & (1) & $(2)$ & (3) & $(4)$ & $(5)$ & $(6)$ & (7) & (8) & (9) \\
\hline \multicolumn{10}{|c|}{ Direct effect of policies/institutions } \\
\hline \multirow[t]{2}{*}{ Average Unemployment } & $0.58^{* * *}$ & $0.57^{* * *}$ & $0.67^{\star * *}$ & $0.55^{\star \star *}$ & $0.58^{* * *}$ & $0.54^{\star \star *}$ & $0.54^{\star \star \star}$ & $0.53^{* * *}$ & $0.53^{\star * *}$ \\
\hline & {$[0.01]$} & {$[0.01]$} & {$[0.01]$} & {$[0.00]$} & {$[0.01]$} & {$[0.01]$} & {$[0.01]$} & {$[0.01]$} & {$[0.01]$} \\
\hline \multirow[t]{2}{*}{$\begin{array}{l}\text { Product market } \\
\text { regulation }\end{array}$} & $0.13^{\star \star \star}$ & $0.33^{* * *}$ & $0.40^{\star \star \star}$ & $0.31^{\star * *}$ & $0.33^{* * *}$ & $0.09^{\star * \star}$ & $0.09^{* * *}$ & $0.08^{* * *}$ & $0.08^{* * *}$ \\
\hline & {$[0.02]$} & [0.02] & {$[0.02]$} & {$[0.02]$} & [0.02] & [0.02] & {$[0.02]$} & [0.02] & {$[0.02]$} \\
\hline \multirow[t]{2}{*}{$\begin{array}{l}\text { Employment protection } \\
\text { for regular employees }\end{array}$} & $0.15^{\star \star \star}$ & $0.33^{* \star *}$ & $0.44^{\star * *}$ & $0.12^{*}$ & $0.20^{\star \star *}$ & 0.01 & $0.12^{*}$ & $0.12^{*}$ & 0.09 \\
\hline & {$[0.07]$} & [0.07] & {$[0.06]$} & {$[0.07]$} & {$[0.07]$} & {$[0.05]$} & {$[0.07]$} & [0.07] & {$[0.07]$} \\
\hline \multirow[t]{2}{*}{$\begin{array}{l}\text { Active labour market } \\
\text { policies }\end{array}$} & $0.01^{\star * *}$ & $0.001^{* * *}$ & $0.01^{* \star *}$ & $-0.01^{* * *}$ & $0.01^{* * *}$ & $-0.02^{* * *}$ & $-0.01^{* * *}$ & $-0.01^{* * *}$ & $-0.01^{* * *}$ \\
\hline & {$[0.00]$} & {$[0.00]$} & {$[0.00]$} & {$[0.00]$} & {$[0.00]$} & {$[0.00]$} & {$[0.00]$} & {$[0.00]$} & {$[0.00]$} \\
\hline \multirow[t]{2}{*}{$\begin{array}{l}\text { Long term } \\
\text { unemployment benefits }\end{array}$} & -0.27 & $-0.93^{* * *}$ & & $-0.63^{\star *}$ & $-0.76^{\star \star \star}$ & & -0.20 & $-0.42^{* *}$ & $-0.39^{\star *}$ \\
\hline & {$[0.21]$} & [0.22] & & {$[0.17]$} & {$[0.23]$} & & {$[0.16]$} & {$[0.18]$} & {$[0.17]$} \\
\hline \multicolumn{10}{|c|}{ Interactions effect of policies/institutions } \\
\hline \multirow[t]{2}{*}{$\begin{array}{l}\text { Product market } \\
\text { regulation *Average } \\
\text { unemployment }\end{array}$} & $0.08^{* * *}$ & & & & & $0.08^{\star \star \star}$ & $0.08^{* * *}$ & $0.08^{* * *}$ & $0.08^{* * *}$ \\
\hline & {$[0.01]$} & & & & & {$[0.01]$} & {$[0.01]$} & {$[0.01]$} & {$[0.01]$} \\
\hline \multirow[t]{2}{*}{$\begin{array}{l}\text { Employment protection } \\
\text { for regular employees * } \\
\text { Average unemployment }\end{array}$} & & $-0.05^{\star \star \star}$ & $0.01^{* *}$ & & & 0.01 & -0.01 & $-0.01^{*}$ & \\
\hline & & {$[0.01]$} & {$[0.00]$} & & & {$[0.00]$} & {$[0.01]$} & {$[0.01]$} & \\
\hline \multirow[t]{2}{*}{$\begin{array}{l}\text { Active labour market } \\
\text { policies * Average } \\
\text { unemployment }\end{array}$} & & & & $-0.01^{* * *}$ & & $-0.01^{* * *}$ & $-0.01^{* * *}$ & $-0.01^{* \star *}$ & $-0.01^{* * *}$ \\
\hline & & & & {$[0.00]$} & & {$[0.00]$} & {$[0.00]$} & {$[0.00]$} & {$[0.00]$} \\
\hline \multirow[t]{2}{*}{$\begin{array}{l}\text { Long-term } \\
\text { unemployment benefits * } \\
\text { Average unemployment }\end{array}$} & & & & & 0.01 & & & $0.12^{* * *}$ & $0.11^{\star * *}$ \\
\hline & & & & & [0.03] & & & [0.03] & {$[0.03]$} \\
\hline Observations included & 379 & 379 & 408 & 379 & 379 & 408 & 379 & 379 & 379 \\
\hline
\end{tabular}

Note: Standard errors of the estimates in brackets. " significant at $10 \%$; ${ }^{* *}$ significant at $5 \%$; ${ }^{* *}$ significant at $1 \%$.

Source: OECD calculations.

14. EPR is found to have a positive impact on the response of long-term unemployment to aggregate unemployment only when it is the only variable interacted with aggregate unemployment and when the sample includes Spain, where there were important regular employment protection reforms in the 1990s (model 3). 


\section{Changes in institutional settings over time have to be taken into account}

16. Not only are institutional settings an important explanation of cross-country differences but as they change over time they may affect the responses of long-term unemployment to changes in aggregate unemployment. The impact derived from time series estimations tends therefore to represent the average response over time and does not necessarily reflect the current institutional settings. In countries that have implemented important labour and product market reforms, the sensitivity of long-term unemployment to aggregate unemployment derived from past relationships may therefore be overstated.

17. A way to assess the impact of changing institutions on the response of long-term unemployment to aggregate unemployment is to compare the predicted response of long-term unemployment to a shock on aggregate unemployment using the average institutional settings over the estimation period and using the most recent institutional settings (Figure 5). ${ }^{15}$ It shows in particular that in European countries, where the changes in institutional settings have been the largest, labour and product market reforms could have reduced the share of additional unemployment that is transmitted into long-term unemployment by 1525 percentage points.

Figure 5. Impact of changing institutions on the response on long-term unemployment to aggregate unemployment

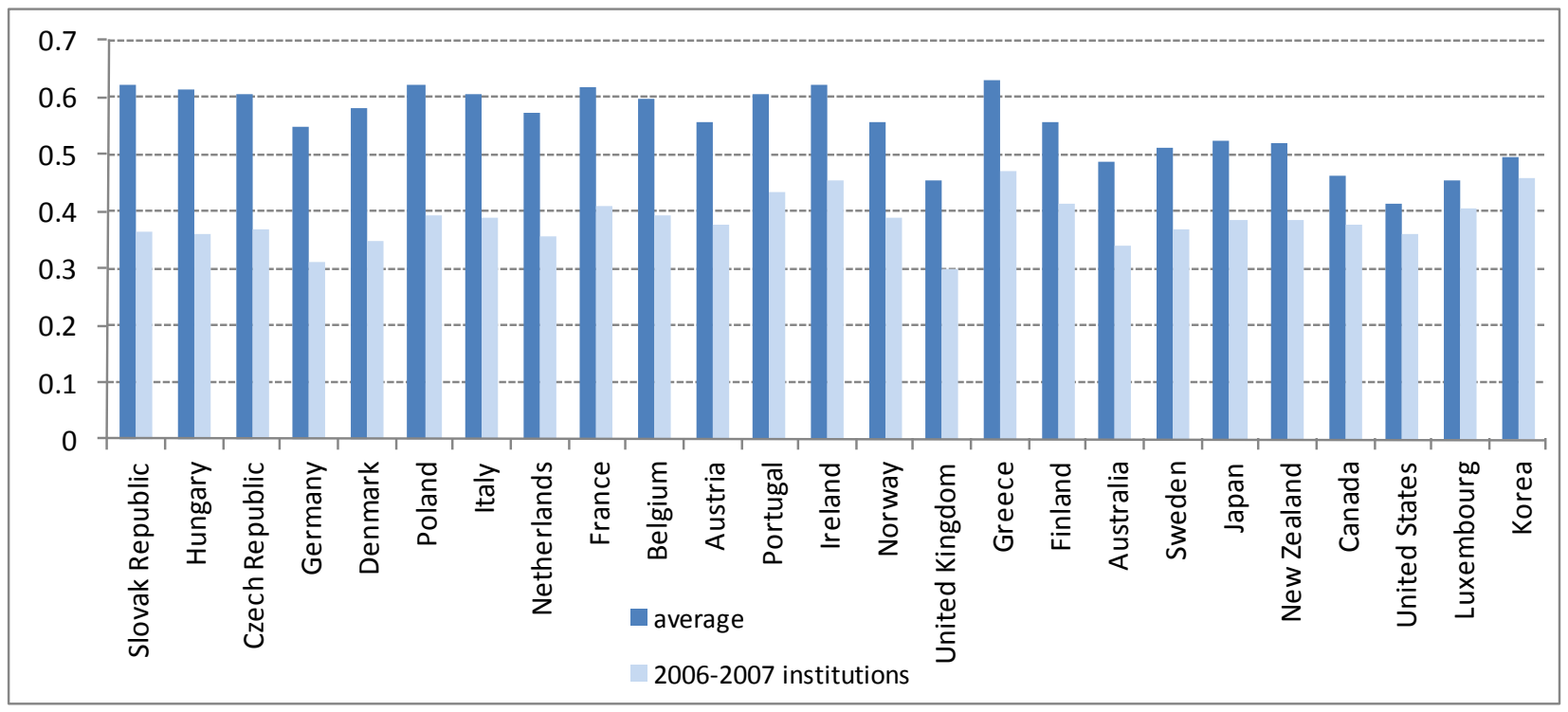

Source: OECD calculations based on Table 2, column 8.

18. The effect of changing institutions shown in Figure 5 can therefore be applied to estimates derived from past relationships (Table 1, last column) to get a more accurate idea of the likely increase of the long-term unemployment implied by the crisis. Overall, long-term unemployment is expected to increase by close to 1 percentage point in the OECD as a whole with the largest increase in Ireland and Spain (Figure 6).

15. This relies on the assumption that the response of long-term unemployment due to variations in unemployment and due to changes in institutions is the same across countries and over time. In practice, however, the results are more likely to have been driven by cross-country differences than the evolution of these variables over time within countries where both unemployment and particularly institutions exhibit much less variance. 
Figure 6. Expected impact of the crisis on long-term unemployment 2007-12

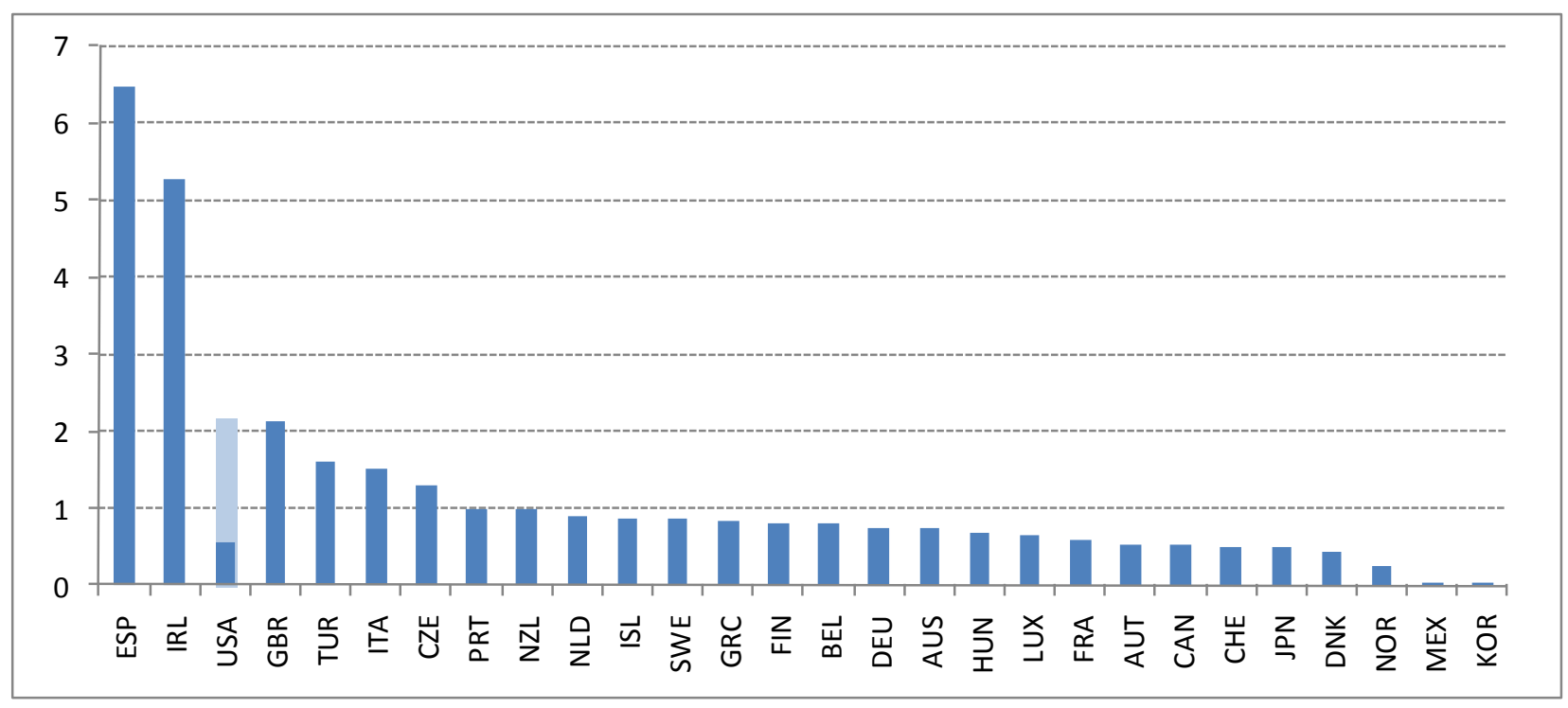

Note: The calculated impact is based on aggregate unemployment projections from the Economic Outlook 86 . For the United States, the dark bar represents the impact derived from historical relationships while the light coloured bar represents the additional impact reflecting recent evolutions. In a few countries (Sweden, Denmark, Germany) ongoing reforms were expected to push down long-term so that the increase in long-term unemployment between 2007 and 2012 is less than the impact of the crisis.

Source: OECD calculations.

19. In the United States, the increase in long-term unemployment already recorded seems by far larger than would be expected from these estimations. The share of unemployed people who have been without a job for at least 27 weeks jumped from below 20\% in 2008 to 44.1\% in March 2010, the highest in post-war history. There is no information on the recent evolution of long-term unemployment (unemployed people who have been without a job for more than year) but based on historical relationships between long-term unemployment and unemployment for more than 27 weeks, long-term unemployment is likely to have increased substantially more than expected. Back-off-the-envelope calculations suggest an increase in long-term unemployment by 1.5 percentage points so far while the overall increase between 2007 and 2012 was estimated at 0.6 percentage points based on historical relationships. It is therefore likely that, overall, the increase in long-term unemployment will be at least three times larger than expected. Further research would be necessary to understand the specificity of the crisis as regards the US labour market, including the sectors most affected (construction, car industry, real estate) and the role played by the housing market crisis in limiting labour force mobility. In the meantime, the relationship between aggregate unemployment and long-term unemployment was arbitrarily recalibrated in order to produce an increase in long-term unemployment more in line with recent developments.

20. For most European countries, the increase in long-term unemployment as measured by Eurostat and available up to 2009Q3 has been quite in line with the projections, with a somewhat stronger-thanexpected increase recorded only in France and Portugal. This is also the case for Australia. But in these three cases, the increase in long-term unemployment recorded so far remains below the total expected by 2012 and may just reflect a faster-than-expected adjustment. 


\section{From long-term unemployment to structural unemployment}

21. The main channel from long-term unemployment to structural unemployment is the lower downward pressure put by long-term unemployed on wages and inflation, relative to the short-term unemployed, as they become less attractive to employers or reduce the intensity of job search. A number of studies, including Elmeskov and MacFarlan (1993) and Llaudes (2005), suggest that across virtually all OECD countries the long-term unemployed exert significantly less pressure on wages than the short-term unemployed so that structural unemployment increases with long-term unemployment. The relationship between long-term unemployment and structural unemployment depends therefore on the relative effect of long and short-term unemployment on wage bargaining and inflation.

22. New empirical has been conducted to assess whether the composition of unemployment mattered for wage pressure. The approach consisted in replicating the work by Gianella et al. (2008) which proposes a time-varying NAIRUs for a panel of OECD economies on the basis of Phillips curve equations using Kalman filter techniques, splitting short-term unemployment and long-term unemployment into two separate components with different weights in the Phillips curve. The original equation was:

$$
\begin{aligned}
\Delta \pi_{i t}=\sum_{i=1}^{p} \alpha_{i l} \Delta \pi_{i t-1}+\beta_{i}\left(U_{i t}-U_{i t}^{k}\right)+\sum_{i=0}^{p} \gamma_{i l} M G S_{i t-l}^{S H}\left(\pi_{i t-l}^{M G S}-\pi_{i t-1}\right) & \\
& +\sum_{i=0}^{p} \delta_{i l} O I L_{i t-l}^{S H}\left(\pi_{i t-l}^{O I L}-\pi_{i t-1}\right)+\varepsilon_{i t}
\end{aligned}
$$

where $\mathrm{U}$ is the unemployment rate, $\mathrm{U}^{*}$ structural unemployment $\pi$ is domestic inflation, $\mathrm{MGS}^{\mathrm{SH}}$ is the import content of consumption, $\pi^{\mathrm{MGS}}$ is import price inflation (goods and services), OIL $^{\mathrm{SH}}$ is the oil intensity of production (calculated as the ratio between oil supply and domestic output), $\pi^{\mathrm{OIL}}$ is oil price inflation.

It is replaced by:

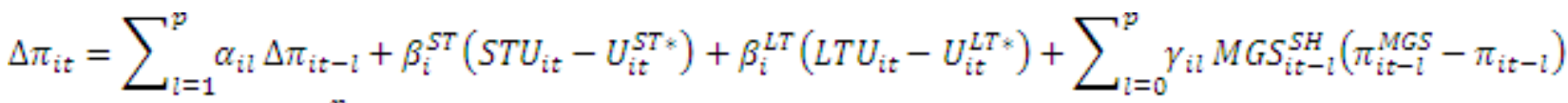

$$
\begin{aligned}
& +\sum_{i=0}^{p} \delta_{i l} O I L_{i t-1}^{S H}\left(\pi_{i t-l}^{O I L}-\pi_{i t-1}\right)+\varepsilon_{i t}
\end{aligned}
$$

where the unemployment gap term is split between a short-term unemployment gap $\left(S T U_{t}-U_{t}^{S T 8}\right)$ and a long-term unemployment gap $\left(L T U_{t}-U_{t}^{L T: 8}\right)$.

23. Results of the Phillips curve estimation presented in Table 4 show that in all European countries (except Luxembourg) the impact of fluctuations in long-term unemployment on inflation is not significant while changes in short-term unemployment play a significant role. ${ }^{16}$ The estimated coefficients of the short-term unemployment gap are also in most of these cases higher than the estimated coefficient of the total unemployment gap suggesting a steeper Phillips curves. Similar results are found in Canada, Australia and New Zealand (with long-term unemployment even reducing wages pressure overall in the last two countries). ${ }^{17}$ On the other hand, in the United States, long-term unemployed seem to keep a role in the

16. The other parameters of the Phillips curve, not reproduced here, are only marginally affected. The results are available upon request.

17. For Australia, the result of a positive impact of long-term unemployment on inflation has also been found by Flatau et al. (1991) as well as Mitchel and Muysken (2002). For both Australia and New-Zealand when 
wage bargaining process. This would suggest that an increase in long-term unemployment is not likely to translate in a comparable increase in the NAIRU as in European countries. ${ }^{18}$

Table 4. A measure of the relative influence of long-term unemployment on inflation

\begin{tabular}{|c|c|c|c|c|c|c|}
\hline & \multicolumn{2}{|c|}{ Gianella et al., 2008} & \multicolumn{4}{|c|}{ New estimations } \\
\hline & $\begin{array}{l}\text { Unemployment } \\
\text { gap }\end{array}$ & $\begin{array}{l}\text { Estimation } \\
\text { period }\end{array}$ & $\begin{array}{l}\text { Unemployment } \\
\text { gap (common } \\
\text { period) }\end{array}$ & $\begin{array}{c}\text { Short-term } \\
\text { unemployment } \\
\text { gap }\end{array}$ & $\begin{array}{c}\text { Long-term } \\
\text { unemployment } \\
\text { gap }\end{array}$ & Estimation period \\
\hline Austria & $-0.43^{\star * \star}$ & 1968Q3-2007Q4 & $-0.29^{\star * *}$ & $-0.30^{\star * \star}$ & -0.15 & 1994Q1-2007Q4 \\
\hline Belgium & $-0.06^{* *}$ & 1961Q1-2007Q4 & $-0.07^{* *}$ & $-0.18^{\star}$ & -0.05 & 1983Q1-2007Q4 \\
\hline Switzerland & $-0.13^{\star \star \star}$ & 1975Q4-2007Q4 & $-0.09^{\star}$ & $-0.18^{\star}$ & -0.01 & 1991Q1-2007Q4 \\
\hline Germany & $-0.08^{\star \star *}$ & 1970Q4-2007Q4 & $-0.07^{* * *}$ & $-0.15^{\star \star}$ & -0.06 & 1983Q1-2007Q4 \\
\hline Denmark & $-0.14^{\star *}$ & 1972Q1-2007Q4 & $-0.11^{\star * *}$ & $-0.18^{\star \star \star}$ & 0.07 & 1983Q1-2007Q4 \\
\hline Spain & & & $-0.04^{*}$ & $-0.13^{*}$ & 0.01 & 1978Q1-2007Q4 \\
\hline Finland & $-0.08^{* * *}$ & 1970Q1-2007Q4 & $-0.05^{\star \star}$ & $-0.06^{*}$ & 0.04 & 1980Q1-2007Q4 \\
\hline France & $-0.15^{\star \star \star}$ & 1970Q4-2007Q4 & $-0.11^{* *}$ & $-0.18^{\star}$ & 0.06 & 1975Q1-2007Q4 \\
\hline $\begin{array}{l}\text { United- } \\
\text { Kingdom }\end{array}$ & $-0.22^{\star * \star}$ & 1970Q4-2007Q4 & $-0.12^{\star *}$ & $-0.28^{\star \star}$ & -0.06 & 1983Q1-2007Q4 \\
\hline Greece & $-0.22^{* *}$ & 1975Q1-2007Q4 & -0.11 & $-0.44^{\star}$ & 0.09 & 1983Q1-2007Q4 \\
\hline Ireland & $-0.09^{* *}$ & 1978Q1-2007Q4 & $-0.06^{\star}$ & $-0.09^{\star *}$ & -0.02 & 1983Q1-2007Q4 \\
\hline Italy & $-0.10^{\star *}$ & 1968Q3-2007Q4 & $-0.08^{* * *}$ & $-0.13^{\star \star \star}$ & 0.06 & 1983Q2-2007Q4 \\
\hline Luxembourg & $-0.24^{* *}$ & 1976Q2-2007Q4 & $-0.22^{* *}$ & -0.03 & $-0.59^{\star * *}$ & 1983Q1-2007Q4 \\
\hline Netherlands & $-0.11^{\star \star \star}$ & 1962Q1-2007Q4 & $-0.08^{\star \star *}$ & $-0.14^{\star \star \star}$ & -0.05 & 1983Q1-2007Q4 \\
\hline Norway & $-0.15^{\star}$ & 1971Q1-2007Q4 & -0.10 & $-0.17^{\star}$ & 0.11 & 1983Q1-2007Q4 \\
\hline Portugal & $-0.21^{* *}$ & 1980Q1-2007Q4 & $-0.11^{* *}$ & -0.17 & -0.07 & 1986Q1-2007Q4 \\
\hline Sweden & -0.07 & 1961Q2-2007Q4 & -0.06 & $-0.16^{\star}$ & 0.17 & 1976Q1-2007Q4 \\
\hline Australia & $-0.20^{\star \star \star}$ & 1964Q1-2007Q4 & $-0.11^{* *}$ & $-0.50^{\star \star \star}$ & $0.39^{\star \star *}$ & 1981Q1-2007Q4 \\
\hline Canada & $-0.11^{\star \star \star}$ & 1962Q1-2007Q4 & $-0.11^{\star \star *}$ & $-0.12^{\star}$ & -0.07 & 1976Q1-2007Q4 \\
\hline Korea & $-0.26^{* *}$ & 1975Q1-2007Q4 & $-0.18^{* *}$ & -0.09 & $-3.97^{\star}$ & 1990Q1-2007Q4 \\
\hline Japan & -0.13 & 1972Q3-2007Q4 & -0.04 & 0.06 & 0.06 & 1977Q1-2007Q4 \\
\hline New-Zealand & $-0.15^{\star *}$ & 1980Q1-2007Q4 & -0.05 & $-0.24^{\star \star}$ & $0.33^{*}$ & 1986Q1-2007Q4 \\
\hline United States & $-0.06^{\star * *}$ & 1965Q2-2007Q4 & $-0.05^{\star \star \star}$ & $-0.05^{\star * *}$ & $-0.16^{\star}$ & 1968Q1-2007Q4 \\
\hline
\end{tabular}

Note: The original equation from Gianella et al. (2008) ( $2^{\text {nd }}$ column) has been re-estimated on the shorter sample where data on long-term unemployment was available $\left(4^{\text {th }}\right.$ column $)$ for sake of comparison.

24. Compared with Llaudes (2005) -- who finds that the relative impact of the long-term unemployed on wages and prices varies across countries and is systematically much lower in Europe than non-European countries, implying that the share of the increase in long-term unemployment that is translated into structural unemployment is larger in Europe than elsewhere, probably reflecting different institutional settings - these results would suggest that long-term unemployed only play a significant role on wage pressure in the United States, Korea and Luxembourg. It is, however, likely in any case that labour market

reducing the estimation period for the past ten years only the effects of long-term unemployment become insignificant.

18. In Japan, no impact of aggregate, long-term and short-term unemployment on inflation could be found, in line with previous research demonstrating that for Japan a significant relationship between inflation and activity is difficult to establish (e.g. Nishizaki, 1997). 
reforms have increased the influence of long-term unemployed on wages and inflation in the other countries and narrowed the gap with the United States. ${ }^{19}$

\section{Overall structural unemployment is expected to increase substantially}

25. A combination of these results has been used to project structural unemployment in the OECD Economic Outlook $86 .^{20}$ Estimation results presented in Table 1 have been corrected to take into account the impact of favourable labour and product market reforms as measured in Figure 5 and applied to the expected peak increase in aggregate unemployment to derive the expected increase in long-term unemployment. It has been assumed that one-third of the increase in long-term unemployment translates into higher structural unemployment in the United States, other non-European economies and the United Kingdom and two-thirds in the rest of Europe.

26. The estimated increase in structural unemployment due to hysteresis effects from 2007 to 2012 is estimated at $3 / 4$ percentage point. It varies widely across countries, reflecting the magnitude of the unemployment shock, current institutional settings and country-specific factors also captured in the longterm relationships (Figure 7). Table 5 summarises the vulnerability of the countries to an increase in structural unemployment based on this two key factors. Overall, the largest increases in structural unemployment are projected in those European countries that are experiencing the largest increase in unemployment and where institutional settings remain less favourable than elsewhere, notably Spain and Ireland. Despite favourable institutional settings, long-term unemployment has already increased substantially in the United-States and the impact of the crisis is higher than suggested by past relationships and the a priori low sensitivity on structural unemployment to increases in aggregate unemployment.

Figure 7. Projected peak increase in the long-term and structural unemployment rate due to the crisis

Percentage points

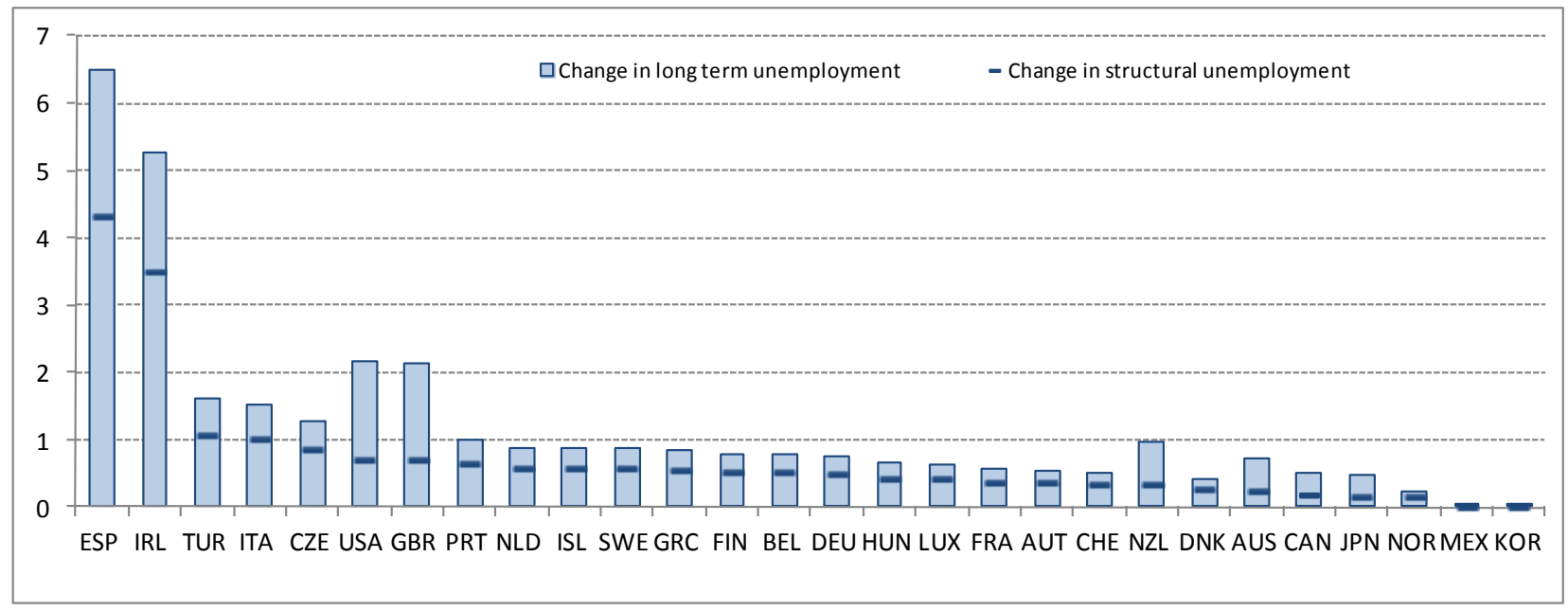

Note: Structural unemployment is expected to fall in Slovakia and Poland as a result of past structural reforms.

Source: OECD Medium-Term Baseline database 86, OECD calculations.

19. Llaudes (2005) finds that employment protection affects particularly the share of long-term unemployment that translated into increases in the NAIRU.

20. The correction to the US projections is not in Economic Outlook 86. 
ECO/WPK(2010)23

Table 5. Summary of the country's vulnerability to an increase in structural unemployment

Relative magnitude of the unemployment shock

\begin{tabular}{|c|c|c|c|}
\hline Sensitivity & Small & Average & Large \\
\hline Low & Korea & $\begin{array}{l}\text { Canada } \\
\text { Mexico }\end{array}$ & $\begin{array}{l}\text { Denmark } \\
\text { Iceland } \\
\text { New Zealand } \\
\text { Sw eden } \\
\text { United States }\end{array}$ \\
\hline Average & $\begin{array}{l}\text { Australia } \\
\text { Austria } \\
\text { Germany } \\
\text { Japan } \\
\text { Norw ay }\end{array}$ & $\begin{array}{l}\text { Finland } \\
\text { France } \\
\text { Hungary } \\
\text { Luxembourg }\end{array}$ & United Kingdom \\
\hline High & $\begin{array}{l}\text { Belgium } \\
\text { Sw itzerland }\end{array}$ & $\begin{array}{l}\text { Greece } \\
\text { Italy } \\
\text { Netherlands } \\
\text { Portugal }\end{array}$ & $\begin{array}{l}\text { Czech Republic } \\
\text { Ireland } \\
\text { Turkey } \\
\text { Spain }\end{array}$ \\
\hline
\end{tabular}

Note: $\quad$ The estimated sensitivity of structural unemployment to aggregate unemployment combines all the underlying assumptions used to derive the response of structural employment to a unit increase in aggregate unemployment following the crisis (including the expected favorable impact of reforms in Sweden, Germany, Denmark). For both dimensions the samples have been divided into three groups of equal size.

Source: OECD. 


\section{BIBLIOGRAPHY}

Bassanini, A. and R. Duval (2006), "Employment Patterns in OECD Countries: Reassessing the Role of Policies and Institutions", OECD Economics Department Working Papers No.486.

Blanchard, O. and J. Wolfers (2000), "The Role of Shocks and Institutions in the Rise of European Unemployment: The Aggregate Evidence," Economic Journal, Royal Economic Society, vol.110(462), pp.C1-33, March.

Boone, J. and J. C. van Ours (2004), "Effective Active Labour Market Policies", IZA Discussion Paper No.1335.

Carey, D. and J. Rabesona (2002), "Tax Ratios on Labour and Capital Income and on Consumption", OECD Economic Studies No35, 2002/2.

Cohen, J. (1978), "Partialed products are interactions; Partialed powers are curve components", Psychological Bullettin, vol.85, 858-66.

Cronbach, L.J. (1987), “Statistical Tests for Moderator Variables.” Psychological Bulletin 87: 51-57.

Elmeskov, J. and M. MacFarlan (1993), "Unemployment Persistence“, OECD Economic Studies, No.21, Paris.

Flatau, P.R., P.E.T. Lewis and A. Rushton, (1991), 'The Macroeconomic Consequences of Long Term Unemployment', Australian Economic Review, 4th Quarter, 48-56.

Friedrich, R. (1982), "In Defense of Multiplicative Terms in Multiple Regression Equations." American Journal of Political Science 26: 797-833.

Furceri, D. and A. Mourougane (2009), "How Do Institutions Affect Structural Unemployment In Times Of Crisis?" OECD Economics Department Working Papers No.730.

Gianella, C., I. Koske, E. Rusticelli, and O. Chatal, (2008), "What Drives the NAIRU? Evidence from a Panel of OECD Countries," OECD Economics Department Working Papers No.649.

Iverson, G. (1991), Contextual analysis. Thousand Oaks, CA: Sage Publications. Series: Quantitative Applications in the Social Sciences, No.81.

Llaudes, R. (2005), “The Phillips Curve and Long-term Unemployment”, ECB Working Paper No.441, February.

Machin, S. and A. Manning (1998), "The Causes and Consequences of Long-Term Unemployment in Europe," CEP Discussion Papers dp0400, Centre for Economic Performance, LSE. 
Mitchell, W. F. and J. Muysken (2002), "The Phillips Curve, The NAIRU, and unemployment asymmetries", Center of Full Employment and Equity Working Paper No. 02-05, University of Newcastle, Australia, 29.

Nickell, S. and R. Layard (1997), "Labour Market Institutions and Economic Performance", Centre for Economic Performance \& Institute of Economics Papers No.23.

Nishizaki, F. (1997), "The NAIRU in Japan: Measurement and its Implications", OECD Economics Department Working Paper No.173.

OECD (2009), Employment Outlook: Tackling the Jobs Crisis, Paris.

OECD (2010), Economic Survey of Germany, Paris.

Richardson, P., L. Boone, C, Giorno, M. Meacci, D. Rae, and D. Turner (2000), "The Concept, Policy Use and Measurement of Structural Unemployment: Estimating a Time Varying NAIRU Across 21 OECD Countries," OECD Economics Department Working Papers No.250. 


\section{WORKING PAPERS}

The full series of Economics Department Working Papers can be consulted at www.oecd.org/eco/working_papers/

766. After the crisis: bringing German public finances back to a sustainable path (May 2010) by Isabell Koske

765. Optimal monetary and fiscal stabilisation policies (May 2010) by Klaus Adam

764. Asset prices and real economic activity (May 2010) by E. Philip Davis

763. Fiscal policy reaction to the cycle in the OECD: Pro- or counter-cyclical? (May 2010) by Balázs Égert

762. New evidence on the private savings offset and Ricardian equivalence (May 2010) by Oliver Röhn

761. Monetary policy reaction functions in the OECD (May 2010) by Douglas Sutherland

760. Counter-cyclical economic policy (May 2010) by Douglas Sutherland, Peter Hoeller, Balázs Égert and Oliver Röhn

759. Exports and property prices in France: are they connected? (April 2010) by Balázs Égert and Rafał Kierzenkowski

758. Further Advancing Pro-Growth Tax and Benefit Reform in the Czech Republic (April 2010) by Zdeněk Hrdlička, Margaret Morgan, David Prušvic, William Tompson and Laura Vartia.

757. Advancing structural reforms in OECD countries: Lessons from twenty case studies (April 2010) by William Tompson and Thai-Thanh Dang

756. Labour markets and the crisis (April 2010)

755. Long-term growth and policy challenges in the large emerging economies (March 2010) by Paul Conway, Sean Dougherty and Artur Radziwill

754. Explaining household saving rates in $G 7$ countries: implications for Germany (February 2010) by Felix Hüfner and Isabell Koske

753. Monetary policy responses to the crisis and exit strategies (February 2010) by Makoto Minegishi and Boris Cournède 
752. Sub-central governments and the economic crisis: impact and policy responses

(February 2010) by Hansjörg Blöchliger, Claire Charbit, José Maria Pinero Campos and Camila

Vammalle

751. Improving China's health care system

(January 2010) by Richard Herd, Yu-Wei Hu and Vincent Koen

750. Providing greater old-age security in China

(January 2010) by Richard Herd, Yu-Wei Hu and Vincent Koen

749. China's labour market in transition: job creation, migration and regulation

(January 2010) by Richard Herd, Vincent Koen and Anders Reutersward

748. A pause in the growth of inequality in China?

(January 2010) by Richard Herd

747. China's financial sector reforms

(January 2010) by Richard Herd, Charles Pigott and Sam Hill

746. A bird's eye view of OECD housing markets

(January 2010) by Christophe André

745. The automobile industry in and beyond the crisis

(January 2010) by David Haugh, Annabelle Mourougane and Olivier Chatal

744 Towards a flexible exchange rate policy in Russia

(December 2009) by Roland Beck and Geoff Barnard

743. Fiscal federalism in Belgium: Challenges and possible improvements

(December 2009) by Willi Leibfritz

742. Product Market Regulation in Russia

(December 2009) by Paul Conway, Tatiana Lysenko and Geoff Barnard

741. How to reform the Belgian tax system to enhance economic growth (December 2009) by Jens Høj

740. Improving the policy framework in Japan to address climate change (December 2009) by Randall S. Jones and Byungseo Yoo

739. Health-care reform in Japan: controlling costs, improving quality and ensuring equity (December 2009) by Randall S. Jones

738. Financial stability: overcoming the crisis and improving the efficiency of the banking sector in Japan

(December 2009) by Randall S. Jones and Masahiko Tsutsumi

737. Recent Oil Price Movements-Forces and Policy Issues

(December 2009) by Eckhard Wurzel, Luke Willard and Patrice Ollivaud 